This is an author produced version of a paper published in Trends in Food Science and Technology.

This paper has been peer-reviewed but may not include the final publisher proof-corrections or pagination.

Citation for the published paper:

Vázquez-Gutiérrez, José L., Langton, Maud. (2015) Current potential and limitations ofimmunolabeling in cereal grain research. Trends in Food Science and Technology. Volume: 41, pp 105-117. http://dx.doi.org/10.1016/j.tifs.2014.10.002.

Access to the published version may require journal subscription. Published with permission from: Elsevier.

Epsilon Open Archive http://epsilon.slu.se 


\title{
Current potential and limitations of immunolabeling in cereal grain research
}

\author{
José L. Vázquez-Gutiérrez* and Maud Langton \\ Department of Food Science, SLU - Swedish University of Agricultural Sciences, PO Box 7051, \\ SE-750 07 Uppsala, Sweden \\ *corresponding author. Tel.: +46 (0)18-671983 \\ E-mail addresses: jose.luis.vazquez.gutierrez@slu.se (J.L. Vázquez-Gutierrez), \\ maud.langton@slu.se (M. Langton)
}

\begin{abstract}
Immunolabeling techniques have made a valuable contribution to cereal grain research during the past decade in terms of precise localization of specific compounds. While these techniques have several limitations, such as the availability and specificity of the antibodies, immunolabeling has proven especially useful in cereal studies seeking a better understanding of grain development and characterization. According to the literature reviewed in this paper, immunolabeling techniques will continue to be a useful tool in the characterization and localization of cereal grain components.
\end{abstract}

\section{Keywords}

Microscopy; grain development; storage protein; antibody 


\section{Introduction}

Immunolabeling has emerged as a powerful investigative tool to localize specific cell components in situ within the complexity of cereal tissues and to integrate tissue-based analysis with proteomic information. Immunolabeling is a method for qualitative or quantitative determination of the presence of a target in a sample, where antibodies are utilized for their specific binding capacity. The antibodies form a complex with the target (antigen), with a detectable label being present on the antibody or on a secondary antibody. The label is a microscopically dense marker that provides a measurable signal by which the binding reaction is monitored, providing a qualitative and/or quantitative measure of the degree of binding. The relative quantity and location of signal generated by the labeled antibodies can serve to indicate the location and/or concentration of the target. The principal differences in immunolabeling methods and materials reside in the type of antibodies generated against the epitopes (monoclonal, polyclonal), the way that the label is attached to the antibody-antigen complex (direct, indirect), the type of label used (e.g., particles such as colloidal gold, fluorescent or phosphorescent compounds, and enzymes such as peroxidase or alkaline phosphatase), and the means by which the antibody-antigen complex is detected (e.g., electron microscopy, light microscopy or fluorescence microscopy).

Both direct and indirect antibody labeling are used for immunolabeling. Direct labeling utilizes only a primary antibody, which is specific for the target and is already bound to the label (Fig. 1a). This simplifies the staining procedure and provides minimal nonspecific staining and less background. Additionally, the direct labeling technique allows the use of two or more primary antibodies of the same species, avoiding the problems with secondary antibody staining. However, each different primary antibody must be tagged, which requires an abundant supply of purified antibody, and the resulting signal is weak since only one labeled primary antibody binds to each antigen. These are the main reasons why, despite the advantages of direct immunolabeling, the indirect approach is more commonly used instead. Indirect immunolabeling involves a multi-step process in which a secondary antibody bound to the label and raised against the $\gamma$ globulin of the primary species is used, e.g. a goat anti-mouse antibody (Fig. 1b). Several labeled secondary antibodies can bind to each primary antibody and therefore the signal is amplified.

To date, no examples of direct labeling can be found in cereal studies. However, some alternative techniques, such as labeled enzymatic probes, have been developed for in situ cell wall analysis and are based on the same philosophy as direct immunolabeling (Dornez, Holopainen, et al., 2011; Wilson, et al., 2006). 

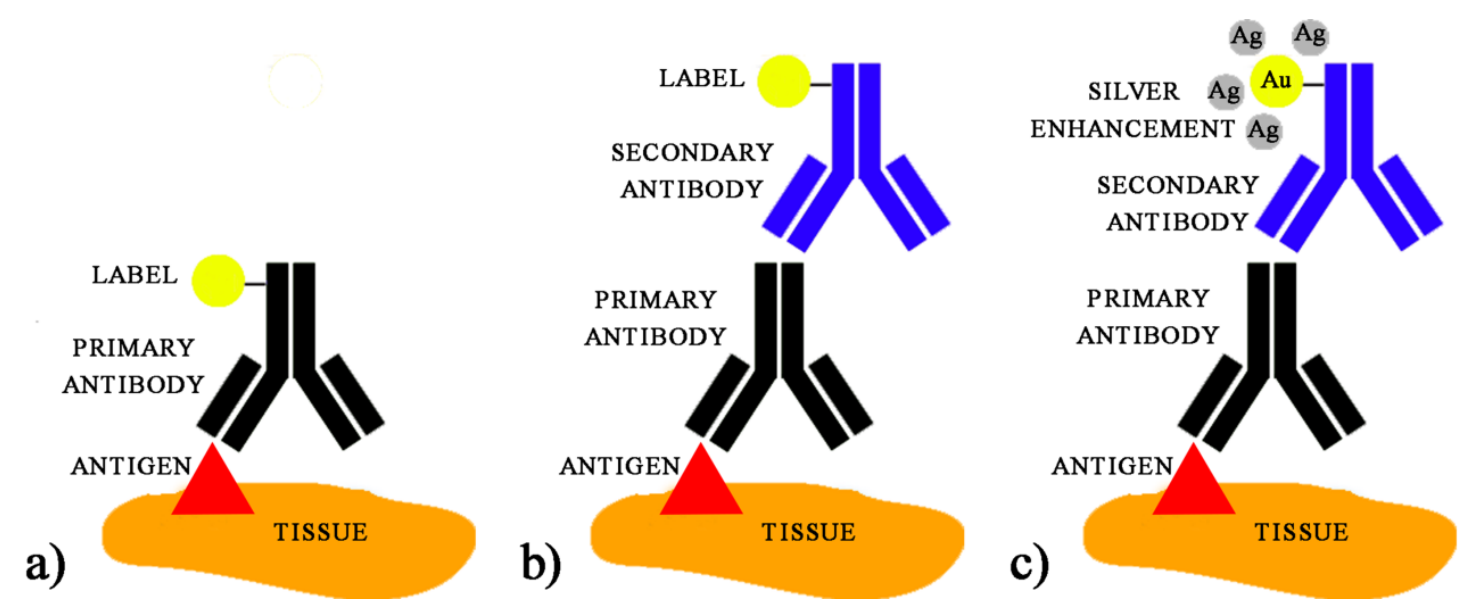

Fig. 1. Schematic representation of immunolabeling mechanisms. a) Direct labeling. b) Indirect labeling; c) Silver-enhanced indirect immunogold labeling.

In most cereal studies, immunogold and immunofluorescence techniques are mainly applied. Figure 2 shows examples of the application of different immunolabeling techniques to localize gluten proteins in wheat endosperm. In the case of immunogold labeling, the cell components are detected using secondary antibodies tagged with electron-dense colloidal gold particles that can be observed by transmission electron microscopy (TEM). The size of the colloidal gold marker bound to the secondary antibody can also be increased using silver enhancement technology (Fig. 1c), so that it can be detected at magnifications appropriate for accurate identification of the labeled compounds in the scanning electron microscope (Mills, et al., 2005) (Fig. 2a), in the light microscope (Van Herpen, et al., 2008) (Fig. 2b) or by confocal laser scanning microscopy (CLSM) (Galuszka, et al., 2005). Silver enhancement is also necessary when the gold particles bound to the secondary antibody are too small to be detected even by TEM (Lesage, et al., 2011). Observation of highly contrasted labeling by light microscopy is also possible using an epipolarization system in which gold particles are visualized as bright spots (Beaugrand, et al., 2005).

In the immunofluorescent labeling technique, fluorochrome-labeled secondary antibodies are used to tag the primary antibodies (Fig. 2c). Immunofluorescent labeled cells are analyzed using a conventional fluorescence microscope or by CLSM, which provides images with high resolution and a 3D reconstruction with a minimum of background noise.

Double immunolabeling allows the detection of two different compounds in the same sample (e.g., two different storage proteins of the grain endosperm) by using two different fluorochromeconjugated antibodies (Furukawa, et al., 2003; Saulnier, Guillon, Sado, \& Rouau, 2007; Washida, et al., 2009) or two antibodies conjugated to gold particles of different sizes (Holding, et al., 2007; Loussert, Popineau, \& Mangavel, 2008) (Fig. 2c and d). 

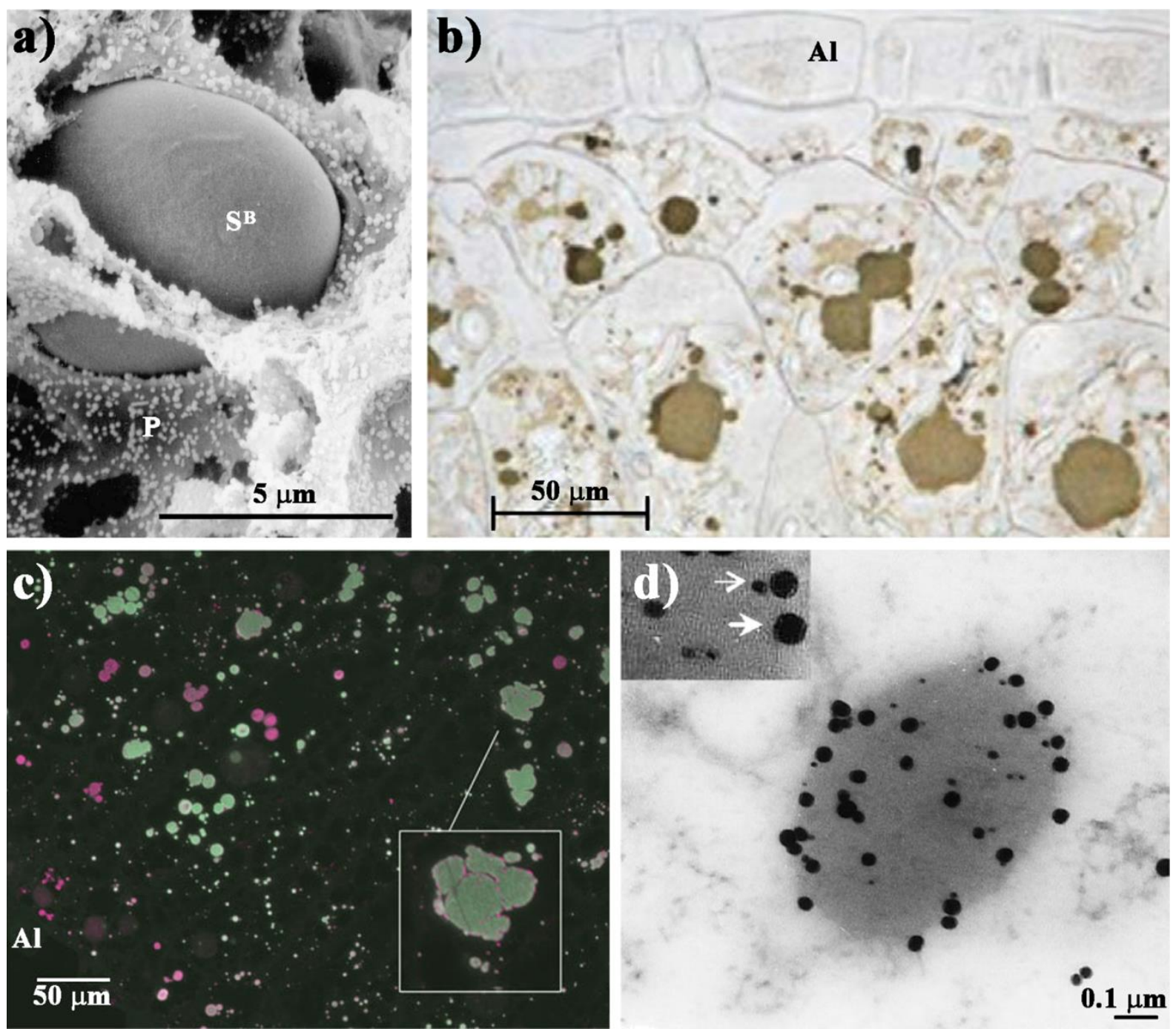

Fig. 2. Immunolocalization of gluten proteins in wheat grain endosperm using different immunolabeling techniques. a) Silver-enhanced immunogold labeling using an anti-gliadin monoclonal antibody observed by scanning electron microscopy in mature starchy endosperm cells. $S^{B}$ : small starch granule; P: protein matrix (Mills, et al., 2005) ${ }^{1}$; b) Silver-enhanced immunogold labeling using anti- $\alpha$-gliadin-specific antibodies observed by light microscopy, 18 days after anthesis (daa) (Van Herpen, et al., 2008) ${ }^{2}$; c) Immunofluorescence double labelling of $\alpha$-gliadin (magenta) and low-molecular weight (LMW) glutenin, 20 daa. (Tosi, et al., 2009) ${ }^{3}$; d) Double immunogold labeling observed by transmission electron microscopy. Small gold particles (empty arrows) were labeled with a monoclonal anti- $\alpha / \beta$-gliadin

\footnotetext{
${ }^{1}$ Reprinted from Journal of Food Science, 41, Mills, E.N.C. et al., Chemical imaging: the distribution of ions and molecules in developing and mature wheat grain, pp. 193-201. Copyright 2005, with permission from Elsevier.

${ }^{2}$ Reprinted from Van Herpen, T.W.J.M. et al., Detailed analysis of the expression of an alpha-gliadin promoter and the deposition of alpha-gliadin protein during wheat grain development, Annals of Botany, 2008, 102, pp. 331-342, by permission of Oxford University Press.

${ }^{3}$ Reprinted from Tosi, P. et al., Trafficking of storage proteins in developing grain of wheat, Journal of Experimental Botany, 2009, 60, 3, pp. 979-991, by permission of Oxford University Press.
} 
antibody. Large gold (full arrows) particles were labeled with a polyclonal anti-LMW glutenin subunit antibody, 15 dAA (Loussert, et al., 2008) ${ }^{4}$.

In addition to immunogold and immunofluorescence labeling, several studies have been carried out using peroxidase- or alkaline phosphatase-linked detection systems (Chen, Chyan, Jiang, Chen, \& Tzen, 2012; Wiley, et al., 2007).

Immunological tissue printing is a simple new technique that consists of transferring cellular material from the freshly cut surface of tissues to appropriate substrate material such as nitrocellulose membranes. The location of proteins, nucleic acids, carbohydrates, and small molecules in a tissue-specific mode can be identified with this technique. Plant tissues can be used to produce prints revealing a remarkable amount of anatomical detail, even without staining, which can be useful in recording developmental changes over time. This technique has been used, for instance, to localize puroindolines in starchy endosperm cells of wheat grain (Wiley, et al., 2007).

Immunolabeling techniques also allow quantitative analyses of compounds by means of quantification of the labeling, usually expressed as the density of gold particles (number of gold particles $/ \mu \mathrm{m}^{2}$ ). When immunofluorescence is applied, the fluorescence intensity can be quantified by image analysis. Ohdaira, et al. (2011) clarified the location and quantity of $13 \mathrm{kDa}$ prolamin and $23 \mathrm{kDa}$ glutelin in different rice cultivars by evaluating relative distance from the outer surface and relative fluorescence intensity, respectively.

The main applications of immunolabeling in grain characterization studies during the past decade are shown in Figure 3. These applications, together with an analysis of the strengths and limitations of this technique in the field of cereal research, are discussed below.

\footnotetext{
${ }^{4}$ Reprinted from Journal of Food Science, 47, Loussert, C. et al., Protein bodies ontogeny and localization of prolamin components in the developing endosperm of wheat caryopses, pp. 445-456. Copyright 2008, with permission from Elsevier.
} 


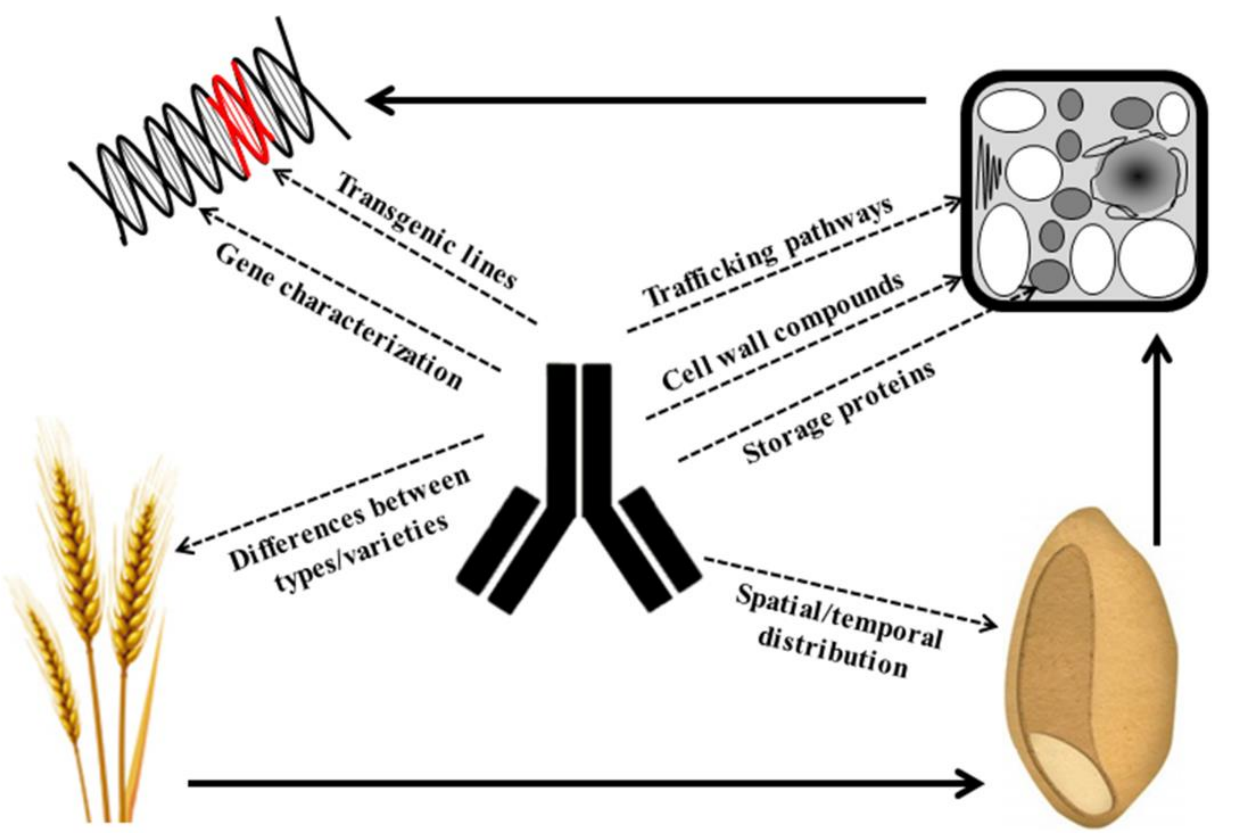

Fig. 3. Schematic representation of the main applications of immunolabeling on cereal grain studies during the last decade.

\section{Localization and characterization of grain components}

Combining the specificity of antibodies with topographical information obtained using microscopy techniques provides information on the distribution of components within cereal grains.

Investigation of plant cells using nondestructive approaches such as immunolabeling has already provided specific information about the distribution of compounds at ultrastructural levels. According to results produced in previous and recent immunolabeling studies on cereals, cell wall polysaccharides and storage proteins have been the main focus (Table 1). Moreover, specific antibodies against other proteins, such as puroindolines (Capparelli, et al., 2005), and phenolic compounds, such as p-coumaric acids (Tranquet, Saulnier, Utille, Ralph, \& Guillon, 2009) have been developed.

\subsection{Cell walls}

For a better understanding of the distribution and functional roles of cell wall polymers, antibodies are required to analyze individual components in situ in relation to intact cell wall architecture. Monoclonal antibodies are specific and sensitive reagents that have been used to show that cell wall composition varies in the walls surrounding a single cell, amongst cell types, and during grain development. Frozen, fractured grains are particularly useful for immunolabeling studies, because the aleurone layer and outer (sub-aleurone) and inner endosperm can be clearly identified on the fracture face (Mills, et al., 2005).

Cereal endosperm cell walls are essentially composed of arabinoxylans $(\mathrm{AX})$ and $(1 \rightarrow 3),(1 \rightarrow 4)$ $\beta$-D-glucans or mixed-linked glucans with minor amounts of cellulose and mannans. Immunolabeling techniques have been applied to improve understanding of the structure and 
properties of cereal cell wall polysaccharides due to their significant commercial value in the enduse of cereal grains and their impact on the nutritional quality of cereal foods as a major constituent of dietary fiber (Saulnier, Guillon, et al., 2007).

The number of antibodies directed against cell wall epitopes has grown steadily over the years. However, until the past decade few antibodies against the cell wall polysaccharide components of the grain had been developed. Polyclonal and monoclonal antibodies had been generated against $(1 \rightarrow 3),(1 \rightarrow 4)-\beta$-D-glucans and arabinogalactan proteins (AGP), whereas only polyclonal antibodies had been produced against AX, p-coumaric acid, or feruloyl-arabinose. Some monoclonal antibodies had also been produced against galactomannan, xyloglucan, homogalacturonan and hydroxyproline-rich glycoprotein (Guillon, et al., 2004; Willats \& Knox, 2003).

Despite this development in antibody production, until recently only a fraction of the molecular structures that make up cell walls were known and understanding of cell wall components was limited. In the past decade, great efforts have been invested in developing antibodies against specific cell wall components. Polyclonal and monoclonal antibodies against different motifs encountered in xylans and AX have now been designed (Guillon, et al., 2004; McCartney, Marcus, \& Knox, 2005; Ordaz-Ortiz, et al., 2004). Monoclonal antibodies against $(1 \rightarrow 3),(1 \rightarrow 4)$ $\beta$-D-glucans (Rampitsch, Ames, Storsley, \& Marien, 2003), xyloglucans (Marcus, et al., 2008), pectic homogalacturonan (Clausen, Willats, \& Knox, 2003; Verhertbruggen, Marcus, Haeger, Ordaz-Ortiz, \& Knox, 2009), xylogalacturonan (Willats, et al., 2004) and p-coumaric acid (Tranquet, et al., 2009), and polyclonal antibodies against ferulic acid (Philippe, Tranquet, Utille, Saulnier, \& Guillon, 2007) have been generated and characterized. Pattathil, et al. (2010) described a comprehensive toolkit of approximately 180 plant cell wall-directed monoclonal antibodies, of which approximately 130 were newly generated. This represents an invaluable increase in the global collection of cell wall glycan-directed monoclonal antibodies and has increased the number of detailed studies on the structure, dynamics, function, and biosynthesis of cell walls in cereals.

Immunolabeling has proven to be very useful in studying the structure and composition of the starchy endosperm and the aleurone of cereal grains (Table 1). However, the outer layers (bran without aleurone), transfer cells, and the embryo (germ) remain less well characterized (Beaugrand, et al., 2005; Chen, et al., 2012; Jerkovic, et al., 2010; Robert, et al., 2011). 
Table 1. Detection of cereal grain components by using immunolabeling techniques.

\begin{tabular}{|c|c|c|}
\hline Part of grain & Compound & Crop \& References \\
\hline \multirow[t]{9}{*}{$\begin{array}{l}\text { Outer layers / Bran } \\
\text { without aleurone }\end{array}$} & Arabinoxylan & $\begin{array}{l}\text { Wheat (Beaugrand et al., 2005; Beaugrand, Reis, et al., 2004; } \\
\text { Dornez, Holopainen, et al., 2011; Philippe et al., 2006; } \\
\text { Philippe et al., 2007); oat, rye, barley (Dornez, Holopainen, et } \\
\text { al., 2011) }\end{array}$ \\
\hline & $(1 \rightarrow 3),(1 \rightarrow 4)-\beta$-D-glucan & Wheat (Philippe et al., 2006) \\
\hline & Callose & Wheat (Philippe et al., 2006) \\
\hline & Ferulic acid & Wheat (Philippe et al., 2007) \\
\hline & Xylanase & $\begin{array}{l}\text { Wheat (Beaugrand, Cronier, et al., 2004; Beaugrand et al., } \\
\text { 2005; Beaugrand, Reis, et al., 2004) }\end{array}$ \\
\hline & Oxalate oxidase & Wheat (Jerkovic et al., 2010) \\
\hline & Xylanase inhibitor I protein & Wheat (Jerkovic et al., 2010) \\
\hline & Wheatwin1 & Wheat (Jerkovic et al., 2010) \\
\hline & Cytokinin dehydrogenase & Maize (Galuszka et al., 2005) \\
\hline \multirow[t]{18}{*}{ Aleurone } & Arabinoxylan & $\begin{array}{l}\text { Wheat (Beaugrand et al., 2005; Beaugrand, Reis, et al., 2004; } \\
\text { Dornez, Holopainen, et al., 2011; Guillon et al., 2004; } \\
\text { Lovegrove et al., 2013; Philippe et al., 2006; Philippe et al., } \\
\text { 2007; Robert et al., 2011; Saulnier, Guillon, et al., 2007; } \\
\text { Suliman et al., 2013); oat, rye (Dornez, Holopainen, et al., } \\
\text { 2011); barley (Dornez, Holopainen, et al., 2011; Wilson et al., } \\
\text { 2012) }\end{array}$ \\
\hline & Xylan & Wheat (Lovegrove et al., 2013) \\
\hline & Xyloglucan & Barley (Wilson et al., 2012) \\
\hline & $(1 \rightarrow 3),(1 \rightarrow 4)-\beta-D-$ glucan & $\begin{array}{l}\text { Wheat (Guillon et al., 2004; Philippe et al., 2006; Robert et al., } \\
\text { 2011; Saulnier, Guillon, et al., 2007); barley (Wilson et al., } \\
\text { 2012) }\end{array}$ \\
\hline & Callose & Wheat (Philippe et al., 2006); barley (Wilson et al., 2012) \\
\hline & Mannan & Barley (Wilson et al., 2012) \\
\hline & Ferulic acid & Wheat (Philippe et al., 2007; Robert et al., 2011) \\
\hline & p-Coumaric acid & Wheat (Robert et al., 2011; Tranquet et al., 2009) \\
\hline & Xylanase & $\begin{array}{l}\text { Wheat (Beaugrand, Cronier, et al., 2004; Beaugrand et al., } \\
\text { 2005; Beaugrand, Reis, et al., 2004) }\end{array}$ \\
\hline & Glycosyltransferase & Wheat (Suliman et al., 2013) \\
\hline & Oxalate oxidase & Wheat (Jerkovic et al., 2010) \\
\hline & Xylanase inhibitor I protein & Wheat (Jerkovic et al., 2010) \\
\hline & Wheatwin1 & Wheat (Jerkovic et al., 2010) \\
\hline & Cytokinin dehydrogenase & Maize (Galuszka et al., 2005) \\
\hline & Prolamin & $\begin{array}{l}\text { Wheat (Gil-Humanes et al., 2011); maize (Reyes et al., 2011); } \\
\text { rice (Saito et al., 2009) }\end{array}$ \\
\hline & Globulin & Wheat (Van Herpen et al., 2008; Wiley et al., 2007) \\
\hline & Oleosin / Caleosin & Rice (Chen et al., 2012); oat (Heneen et al., 2008) \\
\hline & Puroindolines & Wheat (Capparelli et al., 2005) \\
\hline Transfer cells & Arabinoxylan & $\begin{array}{l}\text { Wheat (Dornez, Cuyvers, et al., 2011; Dornez, Holopainen, et } \\
\text { al., 2011; Lovegrove et al., 2013; Robert et al., 2011); oat, rye, } \\
\text { barley (Dornez, Holopainen, et al., 2011) }\end{array}$ \\
\hline
\end{tabular}




\begin{tabular}{|c|c|c|}
\hline Part of grain & Compound & Crop \& References \\
\hline \multirow{17}{*}{ Starchy endosperm } & Xylan & Wheat (Lovegrove et al., 2013) \\
\hline & $(1 \rightarrow 3),(1 \rightarrow 4)-\beta$-D-glucan & Wheat (Robert et al., 2011) \\
\hline & Ferulic acid & Wheat (Robert et al., 2011) \\
\hline & Cell wall invertase & Maize (Kang et al., 2009) \\
\hline & Arabinoxylan & $\begin{array}{l}\text { Wheat (Dornez, Cuyvers, et al., 2011; Dornez, Holopainen, et } \\
\text { al., 2011; Guillon et al., 2004; Lovegrove et al., 2013; Philippe } \\
\text { et al., 2006; Philippe et al., 2007); oat, rye (Dornez, } \\
\text { Holopainen, et al., 2011); barley (Dornez, Holopainen, et al., } \\
\text { 2011; Wilson et al., 2006; Wilson et al., 2012) }\end{array}$ \\
\hline & Xylan & Wheat (Lovegrove et al., 2013) \\
\hline & Xyloglucan & $\begin{array}{l}\text { Wheat (Pellny et al., 2012); barley (Dwivany et al., 2009; } \\
\text { Wilson et al., 2012) }\end{array}$ \\
\hline & $(1 \rightarrow 3),(1 \rightarrow 4)-\beta$-D-glucan & $\begin{array}{l}\text { Wheat (Guillon et al., 2004; Philippe et al., 2006); barley } \\
\text { (Wilson et al., 2006; Wilson et al., 2012); maize (Carpita and } \\
\text { McCann, 2010) }\end{array}$ \\
\hline & Callose & $\begin{array}{l}\text { Wheat (Pellny et al., 2012; Philippe et al., 2006); barley } \\
\text { (Wilson et al., 2006; Wilson et al., 2012) }\end{array}$ \\
\hline & Mannan & $\begin{array}{l}\text { Wheat (Pellny et al., 2012); barley (Wilson et al., 2006; } \\
\text { Wilson et al., 2012) }\end{array}$ \\
\hline & Cellulose & Barley (Wilson et al., 2006) \\
\hline & Ferulic acid & Wheat (Philippe et al., 2007) \\
\hline & Arabinogalactan proteins & Barley (Wilson et al., 2006) \\
\hline & Prolamin & $\begin{array}{l}\text { Wheat (Gil-Humanes et al., 2011; Loussert et al., 2008; Mills } \\
\text { et al., 2005; Tosi et al., 2011; Tosi et al., 2009; Van Herpen et } \\
\text { al., 2008); rice (Furukawa et al., 2003; Nagamine et al., 2011; } \\
\text { Ohdaira et al., 2011; Saito et al., 2009; Saito et al., 2008; } \\
\text { Takahashi et al., 2005; Tian et al., 2013; Washida et al., 2009; } \\
\text { Yasuda et al., 2009); maize (Arcalis et al., 2010; Chikwamba } \\
\text { et al., 2003; Holding et al., 2007) }\end{array}$ \\
\hline & Globulin & $\begin{array}{l}\text { Wheat (Arcalis et al., 2004); rice (Takahashi et al., 2005; Tian } \\
\text { et al., 2013); maize (Arcalis et al., 2010) }\end{array}$ \\
\hline & Glutelin & $\begin{array}{l}\text { Wheat (Arcalis et al., 2004; Wang et al., 2013); rice } \\
\text { (Hennegan et al., 2005; Kawagoe et al., 2005; Takahashi et al., } \\
\text { 2005; Tian et al., 2013; Washida et al., 2009) }\end{array}$ \\
\hline & Albumins & Wheat (Arcalis et al., 2004); rice (Washida et al., 2009) \\
\hline \multirow{8}{*}{$\begin{array}{l}\text { Embryo and } \\
\text { scutellum }\end{array}$} & Oleosin / Caleosin & Oat (Heneen et al., 2008) \\
\hline & Puroindolines & $\begin{array}{l}\text { Wheat (Capparelli et al., 2005; Lesage et al., 2011; Wiley et } \\
\text { al., 2007) }\end{array}$ \\
\hline & Tryptophanin & Oat (Mohammadi et al., 2007) \\
\hline & Binding protein $(\mathrm{BiP})$ & Rice (Takahashi et al., 2005) \\
\hline & Dehydrin & Quinoa (Carjuzaa et al., 2008) \\
\hline & Oleosin / Caleosin & $\begin{array}{l}\text { Rice (Chen et al., 2012); oat (Heneen et al., 2008); barley (Liu } \\
\text { et al., 2005) }\end{array}$ \\
\hline & Prolamin & Rice (Ohdaira et al., 2011) \\
\hline & Cytokinin dehydrogenase & Maize (Galuszka et al., 2005) \\
\hline
\end{tabular}


Specific antibodies have been applied to determine the spatial and temporal distribution of cell wall polysaccharides in different development stages of wheat endosperm (Philippe, et al., 2006) and barley endosperm (Wilson, et al., 2006). Observation of immunogold-labeled cell walls by TEM has been particularly useful in these studies. Some examples of micrographs obtained with this technique are shown in Figure 4.
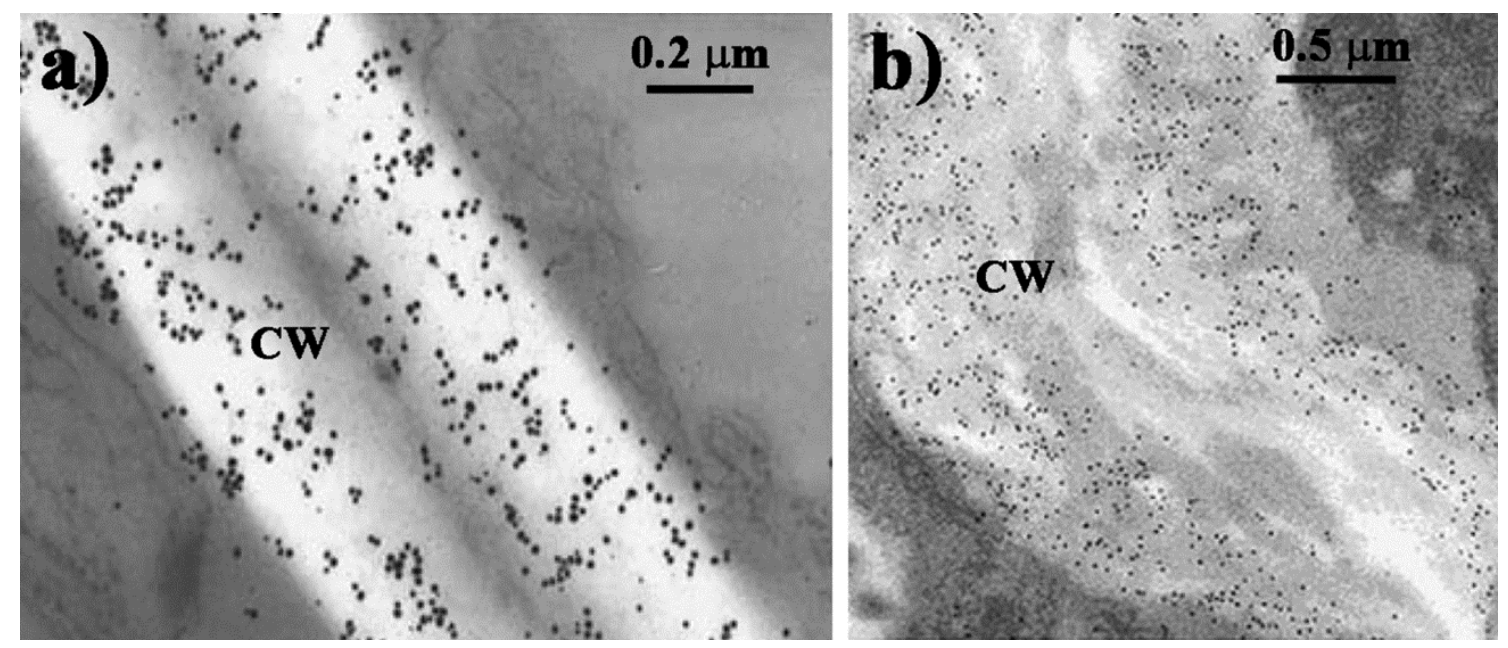

Fig. 4. Transmission electron micrographs of cereal endosperm cell wall immunogold-labeled with anticarbohydrate antibodies. a) $(1 \rightarrow 3),(1 \rightarrow 4)-\beta$-D-glucans in cell walls in central region of wheat starchy endosperm at 446 degree-days (temperature accumulated daily from anthesis) (Philippe, et al., 2006) ${ }^{5}$; b) Arabinoxylan antibody (LM11) labeling in barley endosperm 8 days after pollination: cell walls near the crease were strongly labeled (S. M. Wilson, et al., 2006) ${ }^{6}$. CW: cell wall.

The application of immunolabeling techniques has been useful in identifying significant variations in the amount and structure of non-starch polysaccharides depending on cereal type (Dornez, Holopainen, et al., 2011), tissues (Dornez, Holopainen, et al., 2011; Guillon, et al., 2004; Philippe, et al., 2007; Zhang, et al., 2011), and stages of grain development (Pellny, et al., 2012; Philippe, et al., 2006; Wilson, et al., 2006). Understanding the meaning of such variability and identifying genes controlling the level and structure of cell wall polysaccharides are two key challenges for the development of new cultivars with enhanced nutritional and technological properties (Saulnier, Sado, Branlard, Charmet, \& Guillon, 2007). Guillon, et al. (2004) generated and characterized monoclonal and polyclonal antibodies against $\mathrm{AX}$ and were able to detect variations in structural features of $\mathrm{AX}$, such as the degree of xylose substitution by arabinose within the wheat grain according to cell type. The same antibodies have helped to provide a better

\footnotetext{
${ }^{5}$ Reprinted from Planta, vol. 224, 2006, pp. 456, Arabinoxylan and $(1 \rightarrow 3),(1 \rightarrow 4)-\beta$-glucan deposition in cell walls during wheat endosperm development, Philippe et al., Fig. 6f, copyright 2006, with kind permission from Springer Science and Business Media.

${ }^{6}$ Reprinted from Planta, vol. 224, 2006, pp. 664, Temporal and spatial appearance of wall polysaccharides during cellularization of barley (Hordeum vulgare) endosperm, Wilson et al., Fig. 11c, copyright 2006, with kind permission from Springer Science and Business Media.
} 
understanding of the AX biosynthesis process (Philippe, et al., 2006; Suliman, et al., 2013) and the role of AX substitution in the regulation of water movement within the endosperm (Robert, et al., 2011). Two additional monoclonal antibodies against different epitopes of the xylan backbone, named LM10 and LM11, have been developed recently. LM10 is specific to unsubstituted or low-substituted xylans, whereas LM11 binds to wheat AX in addition to unsubstituted xylans (McCartney, et al., 2005). Consequently, LM11 has proven useful in localizing AX in different cereal grains (Dornez, Holopainen, et al., 2011; Wilson, et al., 2012; Wilson, et al., 2006). Localization of poorly substituted AX has also been achieved by means of anti-(1 $\rightarrow 4)$ - $\beta$-unsubstituted xylan antiserum (Beaugrand, et al., 2005; Beaugrand, Reis, et al., 2004). Using immunolabeling, AX has been detected in the outer layers, aleurone, starchy endosperm, and transfer cells of different cereals (Table 1).

The distribution of $(1 \rightarrow 3),(1 \rightarrow 4)-\beta$-D-glucans in the cell walls of mature wheat grains has been investigated using immunofluorescence (Dornez, Holopainen, et al., 2011; Guillon, et al., 2004; Philippe, et al., 2006; Robert, et al., 2011) and immunogold electron microscopy (Guillon, et al., 2004; Philippe, et al., 2006), using a specific monoclonal antibody. The location of $(1 \rightarrow 3),(1 \rightarrow 4)-\beta$-D-glucans has also been identified by immunolabeling in other cereals such as barley (Dornez, Holopainen, et al., 2011; Wilson, et al., 2006), maize (Carpita \& McCann, 2010), oat (Dornez, Holopainen, et al., 2011) and rye (Dornez, Holopainen, et al., 2011). In addition to their localization, a better understanding of $(1 \rightarrow 3),(1 \rightarrow 4)$ - $\beta$-D-glucan biosynthesis (Carpita \& McCann, 2010; Robert, et al., 2011; Wilson, et al., 2006) and function (Guillon, et al., 2004; Robert, et al., 2011) has been achieved by immunolabeling.

The immunolabeling of $\mathrm{AX},(1 \rightarrow 3),(1 \rightarrow 4)-\beta$-D-glucans, and other minor polysaccharides in cereal cell walls, such as xyloglucans, mannans, callose, and cellulose, has allowed monitoring of cell wall formation in the endosperm of developing wheat (Pellny, et al., 2012; Philippe, et al., 2006) and barley (Wilson, et al., 2006), in order to define the temporal and spatial pattern of deposition of cell wall components. In combination with quantitative (q)-PCR or quantitative reverse transcription (qRT)-PCR analyses, it has also helped to identify candidate genes responsible for cell wall composition (Pellny, et al., 2012; Wilson, et al., 2012). Wilson, et al. (2006) shed some light on the sequence of deposition of individual cell wall polysaccharides in developing barley endosperm by immunolabeling of polysaccharides, which showed initial deposition of callose and cellulose, followed by $(1 \rightarrow 3),(1 \rightarrow 4)-\beta$-D-glucans, hetero- $(1 \rightarrow 4)-\beta$ mannans, AGP, and AX. Similar sequencing in wheat endosperm for callose, $(1 \rightarrow 3),(1 \rightarrow 4)-\beta$-Dglucan, and AX has been reported using immunolabeling (Philippe, et al., 2006).

In contrast to the aleurone layer and the starchy endosperm, other parts of the grain such as the transfer cells, which are involved in nutrient transfer from the maternal tissues to the developing endosperm, have not been extensively studied in terms of structure and composition. Robert, et al. (2011) focused on characterization of the polysaccharides $(1 \rightarrow 3),(1 \rightarrow 4)-\beta$-D-glucans and AX and on the aromatic composition of transfer cell walls of wheat by immunolabeling, and Fourier transform infrared (FT-IR) and Raman micro-spectroscopy. However, AX and $(1 \rightarrow 3),(1 \rightarrow 4)-\beta$ - 
D-glucans were not stained in the transfer cells when four different grain cell wall staining techniques, including immunolabeling were applied in a different study on wheat, barley, oat, and rye (Dornez, Holopainen, et al., 2011).

A better understanding of the outer layers of cereal grain has been obtained in the past few years (Beaugrand, Cronier, et al., 2004; Beaugrand, et al., 2005; Beaugrand, Reis, et al., 2004; Dornez, Holopainen, et al., 2011; Jerkovic, et al., 2010; Philippe, et al., 2007). For example, Beaugrand, Cronier, et al. (2004) evaluated the impact of outer-layer changes across grain ripening on in situ degradation of $\mathrm{AX}$ in the peripheral grain tissues by immunolocalization of a $(1 \rightarrow 4)$ - $\beta$-endoxylanase. Beaugrand, et al. (2005) revealed a degree of cellular heterogeneity in wheat bran based on differences in AX labeling density.

Some other cell wall compounds have been localized by immunolabeling. AGP-specific monoclonal antibodies have helped to reveal the developmental dynamics of AGP glycan structure and represent a diagnostic tool for AGPs. Frequently used anti-AGP monoclonal antibodies are JIM8, JIM13, JIM14, LM2, and CCRC-M7. In primary and secondary walls of cereals, ferulic acid and p-coumaric acid are predominant among the hydroxycinnamic acids. They contribute to cell wall assembly, promote tissue cohesion, and restrict cell expansion. Immunocytochemistry is very sensitive and potentially more specific for the in situ analysis of cell wall phenolic constituents than other methods such as Ramman spectroscopy (Tranquet, et al., 2009). The characterization of a polyclonal antibody against 5-O-(trans-feruloyl)-L-arabinose and two monoclonal antibodies useful for the detection of p-coumaric acid has recently been reported (Philippe, et al., 2007; Tranquet, et al., 2009). These antibodies have been used to localize ferulic acid and p-coumaric acid, to compare the degree of feruloylation of $\mathrm{AX}$ in transfer and aleurone cells, and to monitor changes in p-coumaric acid esters in the cell wall of wheat grains during development (Philippe, et al., 2007; Robert, et al., 2011; Tranquet, et al., 2009).

\subsection{Grain proteins}

Depending on their function, cereal proteins can be classified into storage, structural, metabolic and protective proteins. The storage proteins are the most abundant proteins in cereal grains and have important impacts on the nutritional quality for humans and livestock and on the functional properties in food processing. Immunolabeling has contributed to the study of storage proteins in cereals (Table 1).

Gluten proteins are the major storage protein fraction in the mature wheat grain and interact during grain development to create large polymers, which form a continuous proteinaceous network when flour is mixed with water to make dough. Immunofluorescence and immunogold labeling of gluten proteins has allowed determination of quantitative and qualitative gradients in gluten protein composition (Tosi, et al., 2011), their trafficking pathways (Tosi, et al., 2009), and their processes of expression and deposition (Van Herpen, et al., 2008; Wang, et al., 2013) during grain development. These findings are of particular interest because of the major role played by 
the gluten proteins in determining grain processing quality. Immunolabeling has revealed that prolamin proteins are heterogeneously deposited, not only throughout the wheat endosperm, with the outer endosperm containing a much greater proportion of prolamins than the inner endosperm (Mills, et al., 2005). Prolamin proteins are also heterogeneously deposited within the endosperm cells themselves (Tosi, et al., 2009). These protein gradients have been subsequently investigated in detail using antibodies recognizing specific gluten protein types (Tosi, et al., 2011). However, according to Loussert, et al. (2008) immunochemical labeling of prolamins has failed to reveal in TEM analyses any particular internal organization in protein bodies, since all prolamins studied occurred in the same protein bodies, without any segregation according to type.

In other cereals, immunochemical experiments have been carried out to identify the distribution of prolamin proteins and characterize the accumulation process of these proteins in developing and mature rice grains (Nagamine, et al., 2011; Saito, et al., 2009; Saito, et al., 2008; Takahashi, et al., 2005). Storage protein distribution in different rice cultivars has also been compared (Furukawa, et al., 2003; Ohdaira, et al., 2011). Moreover, these techniques have been used to characterize the structure of processed rice protein and relate it to its digestibility (Kumagai, et al., 2006). Meanwhile, Reyes, et al. (2011) studied the synthesis and transport of storage proteins in maize aleurone cells and concluded that their trafficking pathway may be a widespread mechanism for vacuolar delivery of prolamins in cereals. Double immunolabeling in combination with image analysis has been used to determine differences in the distribution of zeins between wild and mutant maize cultivars (Holding, et al., 2007).

In order to investigate the mechanisms of synthesis and deposition of storage proteins and to gain an insight into the relationship between RNA and protein localization, immunolabeling has been applied to transgenic lines of wheat (Arcalis, et al., 2004; Gil-Humanes, et al., 2011; Tosi, et al., 2009; Van Herpen, et al., 2008), rice (Kawagoe, et al., 2005; Kawakatsu, Hirose, Yasuda, \& Takaiwa, 2010; Saito, et al., 2009; Shigemitsu, Masumura, Morita, \& Satoh, 2013; Tian, et al., 2013; Wakasa, Yang, Hirose, \& Takaiwa, 2009; Wakasa, et al., 2011; Washida, et al., 2009; Yasuda, et al., 2009), and maize (Arcalis, et al., 2010). These lines have been essential in studies of the formation and fusion of protein bodies in developing grains.

Other group of proteins related to grain softness, and therefore affecting both milling and baking properties, are puroindolines. The location of puroindolines by immunolabeling has been used in studies of their antibacterial properties (Capparelli, et al., 2005) and their impact on the aggregation of storage proteins (Lesage, et al., 2011). Wiley, et al. (2007) provided clear evidence on the synthesis and accumulation of puroindolines by applying immunolocalization with alkaline phosphatase labeling of tissue prints. Antibodies against puroindolines and friabilin have been used to localize their counterparts in oat seed, tryptophanins, and study their changes during seed development and germination (Mohammadi, et al., 2007).

The lipid matrix of the oil bodies from cereal grain is surrounded by a monolayer of phospholipids embedded with unique proteins. This has permitted oleosin and caleosin to be 
immunolocalized in rice grains for their characterization (Chen, et al., 2012) and in oat (Heneen, et al., 2008) and barley (Liu, et al., 2005) in order to elucidate their role in oil body formation.

The metabolism of cell wall polysaccharides requires the involvement of numerous enzymes. Suliman, et al. (2013) recently identified glycosyltransferases involved in wheat endosperm cell wall formation. Immunogold labeling and silver enhancement were used in their study in order to localize AX and a polypeptide associated to the Golgi apparatus using TEM analyses. The flavoprotein cytokinin dehydrogenase controls the degradation of cytokinins, which are plant hormones that contribute to the regulation of numerous developmental processes. Histochemical localization of cytokinin dehydrogenase by activity staining and immunochemistry using optical and confocal microscopy have shown that cytokinin dehydrogenase is most abundant in the aleurone layer of maize kernels and in phloem cells of seedling shoots (Galuszka, et al., 2005).

\section{Challenges and limitations of immunolabeling}

\subsection{Availability of specific antibodies}

Polyclonal antibodies are sera containing a heterogeneous complex mixture of antibodies with different specificities and epitope affinities against one antigen and are therefore non-specific. Monoclonal antibodies consist of only one antibody subtype which detects only one specific epitope of the antigen (Fig. 5). Generation of antisera is easier and less time consuming compared to monoclonal antibodies. However, generation of hybridoma monoclonal antibodies derived from cell-based isolation procedures is currently the most effective way to generate antibodies with higher specificity.
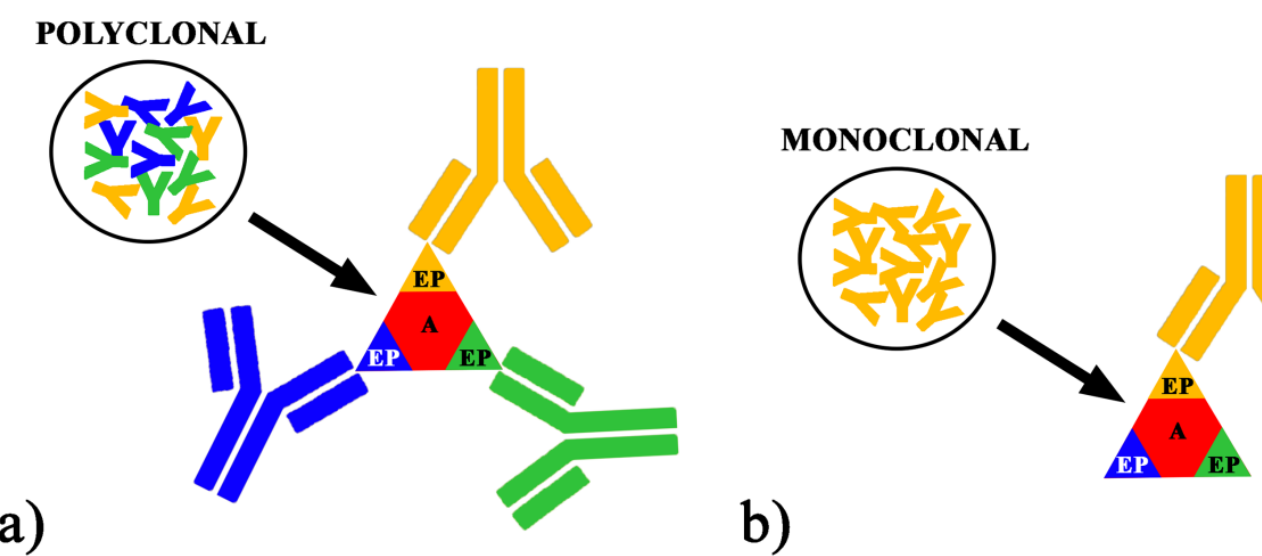

b)

Fig. 5. Schematic representation of a) polyclonal and b) monoclonal antibodies. A: antigen; EP: epitope.

Different information may be obtained depending on whether monoclonal or polyclonal antibodies are used, as occurred in recent studies regarding the location of puroindolines in the aleurone of wheat grain (Capparelli, et al., 2005; Wiley, et al., 2007). Both polyclonal and monoclonal antibodies have their advantages which make them useful depending on the application. Polyclonal antibodies can help amplify signal from target proteins with low 
expression level, since they can bind each target molecule on multiple epitopes. However, polyclonal antibodies are not useful in studies probing specific domains of the antigen or quantifying labeling. The high specificity of monoclonal antibodies, on the other hand, decreases background noise and cross-reactivity and helps provide reproducible results. However, this also makes monoclonal antibodies more sensitive to antigen changes and loss of reactivity.

The generation of antibodies to the polysaccharide and phenolic components of cell walls is generally less straightforward than the generation of antibodies to proteins and the peptide components of glycoproteins (Willats \& Knox, 2003). The lack of appropriate antibodies for specific purposes has been a limitation in recent studies on cell wall characterization (Philippe, et al., 2006; Robert, et al., 2011) and metabolic processes (Galuszka, et al., 2005). The amount of commercial antibodies available for cereal research purposes is limited (Table 2) and the development of specific antibodies in the laboratory is a long and complicated process. Despite this, the specificity and variety of available antibodies have progressively increased during recent years, offering new opportunities in cereal research. The available antibodies are becoming more sophisticated and permit description of spatial and temporal variations in the structure that could not be determined by other chemical analysis techniques (Wilson, et al., 2012).

Table 2. Commercial antibodies used in cereal research during the last decade.

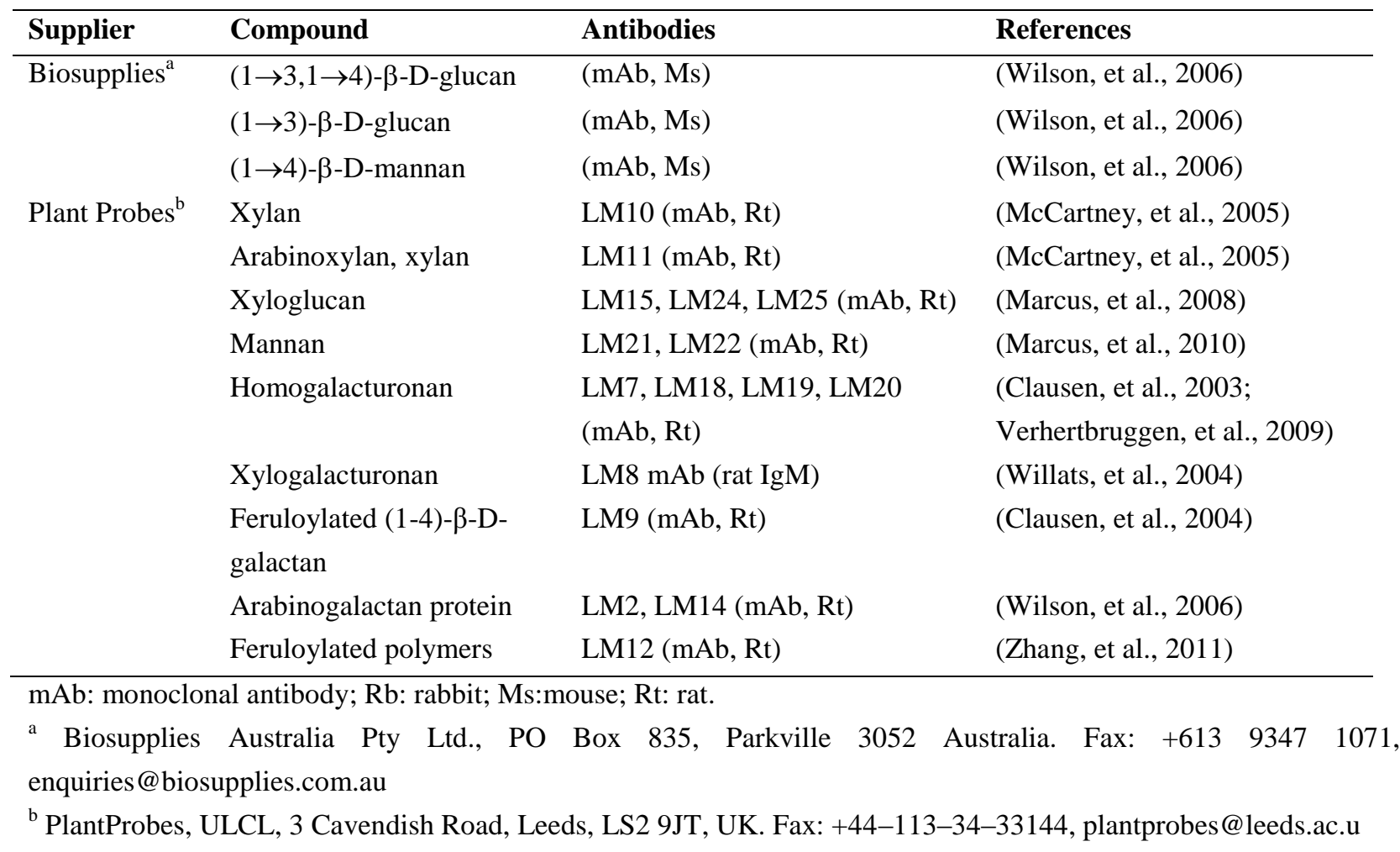

However, the intermolecular interactions of $(1 \rightarrow 3),(1 \rightarrow 4)-\beta$-D-glucans and AX and their role in cell wall properties have not been extensively explored (Philippe, et al., 2006; Robert, et al., 2011). The development of new antibodies against cell wall compounds, such as highly substituted AX, would contribute to a better understanding of the role of these polysaccharides in 
cereal cell wall. Although the monoclonal antibody LM11 binds to a certain extent to maize glucuronoarabinoxylans (McCartney, et al., 2005), an antibody specific against these compounds has yet to be developed. In the same way, antibodies directed against ferulic acid dehydrodimers are needed to better understand their role in cell wall structure and tissue adhesion. To date, the polyclonal antibody anti-5-O-Fer-Ara has been used, based on the assumption that the amount of dehydrodimers is proportional to that of esterified ferulic acid (Philippe, et al., 2007).

\subsection{Antibody specificity}

Despite the superior specificity of the antibodies compared with conventional histological staining agents, the suitability of an antibody depends on the number of potential binding sites for the probe on the target compound. This makes it more difficult to detect diffuse proteins than aggregated proteins by immunocytochemistry (Saito, et al., 2009). In the case of AX, the antibodies developed clearly differ in specificity and react with different AX epitopes. The monoclonal antibody anti-AX1 and the polyclonal serum anti-X3 both bind unsubstituted $\beta$ $(1 \rightarrow 4)$ xylosyl sequence, but differ in their capacity to recognize substituted AX (Guillon, et al., 2004; Ordaz-Ortiz, et al., 2004). The polyclonal anti-X3 antibody requires a sequence of three unsubstituted xylose residues for maximum affinity, while the monoclonal anti-AX1 antibody has higher affinity for xylosaccharides containing arabinose, and the monoclonal LM10 only binds to un-substituted or low substituted xylans (Guillon, et al., 2004; McCartney, et al., 2005). The recently developed LM11 monoclonal antibody had originally been shown to bind to wheat arabinoxylan in addition to unsubstituted xylans (McCartney, et al., 2005). However, its effectiveness in detecting arabinoxylans is highly influenced by their degree of substitution, and this has led to different conclusions about the temporal and spatial deposition of these polysaccharides during grain development (Wilson, et al., 2006). Nevertheless, this limitation has been solved by pretreating sections with $\alpha$-L-arabinofuranosidase, therefore exposing the epitopes needed for antibody recognition (Wilson, et al., 2012). An antibody binding to highly substituted AX remains to be developed. In certain organs, large sets of xyloglucan and mannan epitopes are masked by the presence of pectic homogalacturonan, which limits the understanding of xyloglucan function in primary cell walls (Marcus, et al., 2010; Marcus, et al., 2008). The use of enzymatic degradation in conjunction with cell wall probes is likely to be an important analytical tool in studies on the developmental regulation of links between pectic polymers and xyloglucan (Marcus, et al., 2008).

Some authors have suggested that low intensity labeling of $\mathrm{AX}$ and $(1 \rightarrow 3),(1 \rightarrow 4)-\beta$-D-glucan could be due to their epitopes being masked by other deposited polymers or substituents (Philippe, et al., 2006; Wilson, et al., 2006).

Discrepancies between immunogold labeling and other immunoanalyses such as ELISA and Western blot analysis, have been reported and two different explanations have been proposed. The antibody-reactive epitopes could be affected by the tissue preparation procedures required for 
microscopy observation, or the sensitivity level of the immunogold detection technique could be higher than that of the other immunotechniques (Chikwamba, et al., 2003).

In order to avoid false positives when applying indirect immunolabeling, all experiments should be performed with a series of controls conducted simultaneously. In general, not all the different types of control are evaluated in each study, but at least one or two types of control are tested. The most common control tests carried out are the omission of primary or secondary antibodies to certify that the labeling intended is the result of the antibody-antigen interaction, and incubation with preimmune serum instead of the primary antibody to ensure that no component in the immune serum other than the specific $\mathrm{IgG}$ is responsible for the binding. Other types of control consist of reaction of the primary antibody with an excess of antigen to show that only the antigen is responsible for the localization seen, or the use of an unlabeled antibody to determine that the specific properties of the labeled antibody are responsible for the localization.

In the case of polyclonal antiserum, antibodies that can react with other antigens may induce nonspecific labeling during immunostaining of the compound of interest. Therefore, treatment of the antiserum in order to remove the nonspecific binding groups is necessary (Beaugrand, Reis, et al., 2004).

\subsection{Tissue preparation and methodology limitations}

Preparation of the sample is critical to maintain cell morphology, tissue architecture and the antigenicity of target epitopes. Frozen, fractured grains are particularly useful for immunolabeling studies, because the aleurone, sub-aleurone and inner endosperm layers can be clearly identified on the fracture face (Mills, et al., 2005). Ultrastructural preservation in immunoelectron microscopy is usually compromised because the fixatives used may prevent the antibody-epitope reaction. For example, formalin fixation renders epitopes inaccessible to antibody recognition, while glutaraldehyde and/or osmium tetroxide does not interfere with carbohydrate epitope labeling, but high concentrations of these fixatives should be avoided for protein labeling. Moreover, the inherent features of plant cells, such as their hydrophobic surfaces, rigid cell walls, and large vacuoles, complicate the exchange of reagents. Hence, achieving ultrastructural preservation while protecting the antigenicity of molecular epitopes has proven difficult in plant tissues. Wilson and Bacic (2012) examined a traditional, chemical-based protocol and a method based on cryofixation techniques, including high-pressure freezing, and freeze-substitution, and found that both methods provide good ultrastructural detail in plant cells, while preserving the binding capacity of carbohydrate and protein epitopes. However, immunolabeling in combination with cryofixation and freeze-substitution techniques provides more detailed information on the immunoelectron-microscopic localization of molecules in the plant cell and superior immunolocalization of protein antigens than can be obtained from chemically fixed tissues. Takeuchi, Takabe, and Mineyuki (2010) also introduced methods for immunoelectron microscopy of post-embedded, cryofixed plant tissues by applying an antibody to a thin plastic resin-embedded section prepared by cryofixation followed by freeze-substitution. 
One of the limitations of immunolabeling plastic sections is difficulty in penetration of the labels after embedding. For formalin-fixed paraffin-embedded tissues, antigen retrieval is often necessary, and involves exposing the tissue sections to heat or proteolytic enzyme. The preparation of thin sections of most mature cereal grains for cytochemical analysis is difficult. Rice is especially difficult in this regard, because its endosperm tissue is hard. Saito, et al. (2008) recently developed the frozen film method, which consists of using an adhesive film to avoid damaging frozen sections during cutting. This allows histological sections of mature rice grains to be obtained for morphometric investigations and for immunohistochemical experiments.

Although immunolabeling can provide a semiquantitative assessment of gene expression levels, the limitations of this method prevent fully stoichiometric assessment of protein expression per cell. Wiley, et al. (2007) provided clear evidence that puroindolines are only synthesized and accumulated in the starchy endosperm cells of the wheat grain by immunolocalization with alkaline phosphatase labeling of tissue prints. However, the immunochemical analysis measured the total accumulated proteins and was not able to confirm the difference in distribution between the central and outer layers of the starchy endosperm shown by $\beta$-glucuronidase (GUS) expression assays.

Despite its limitations, immunolabeling is a complementary technique to other analytical and staining methods in revealing the location and distribution of the major cereal components (Dornez, Holopainen, et al., 2011). Immunolabeling in combination with Fourier-transform infrared microspectroscopy (Mills, et al., 2005; Toole, et al., 2012) has helped to provide a more complete picture of the changes in $\mathrm{AX}$ structure during grain development and its distribution within the grain. A combination of immunolabeling and $\mathrm{N}$-glycan analysis of recombinant proteins has proven useful in elucidation of protein trafficking pathways in cereals (Arcalis, et al., 2004; Arcalis, et al., 2010). Similarly, Jerkovic, et al. (2010) applied immunofluorescence overlaid on differential interference contrast (DIC) images to confirm the location of three major defense proteins identified in different wheat bran fractions and to place them in a functional framework.

\section{Future perspectives and conclusions}

Immunolabeling has been applied consistently in a wide variety of cereal grain studies during the past decade. According to the literature included in this review, these techniques can be expected to remain in use, representing a useful tool in the characterization and localization of cereal components. Although fine spatial and temporal tuning of the biosynthesis of cell wall polymers has been achieved in recent years, further studies are needed to fully understand the heterogeneity of cell wall structure in cereal endosperm, and immunolabeling will be essential in this regard. Combined with the great advances in the past decade, the future development of more antibodies against specific fiber and protein fractions will contribute even more to a deeper understanding of cereal grain structure. Another step forward will be to study the relationship between this spatial, 
compositional information and grain properties, such as biomechanical properties that can affect the milling process.

Progress towards establishing plants as a vehicle for the production of plant-made pharmaceuticals is likely to accelerate in the coming years (Hensel, 2011). The achievement of appropriate levels of expression remains somewhat empirical, and to a large extent varies from one recombinant protein to another (Hensel, 2011). Therefore, immunolabeling of recombinant proteins will be necessary in order to understand pathways and biochemical processes yet to be unraveled (Finnie, Sultan, \& Grasser, 2011).

It can also be concluded from this review of the literature that there are areas in cereal research where the potential of immunolabeling has not been properly explored as yet. New allergenspecific antibodies may be developed and used to localize allergens in cereal grains by immunolabeling, as has been already done in the characterization of a wheat serine proteinase inhibitor (Constantin, et al., 2008) and different gluten fractions (Mitea, et al., 2008; Tranquet, Larré, \& Denery-Papini, 2012). Immunolabeling may also be useful to evaluate the degradation of different components of cereals and cereal products during digestion. Moreover, most of the applications of immunolabeling have focused on wheat, rice, and maize, while studies using this technique for other cereals such as oat or rye have been relatively scarce. The potential of immunolabeling techniques could also be applied to cereal-derived products such as bread, porridge or extruded cereal.

The use of Arabidopsis thaliana and rice as model plants has greatly accelerated research in cereal biology (Pattathil, et al., 2010). However, these plant models present drawbacks to addressing biological questions related to temperate grasses. Several studies using immunolabeling techniques have sought to gain insights into the usefulness of Brachypodium distachyon as a model for studies on cell walls (Guillon, et al., 2011) and storage proteins (Larré, et al., 2010) in cereal grains. Therefore, immunolabeling techniques are expected to be useful in future studies on $B$. distachyon.

To sum up, immunolabeling techniques have made a valuable contribution to cereal grain characterization during the past decade when precise localization of specific compounds has been required. These techniques are especially useful in cereal studies seeking a better understanding of grain development and characterization.

\section{Acknowledgements}

The authors wish to thank Mary McAfee, who assisted in the English grammar improvement of the manuscript. 


\section{Reference list}

Arcalis, E., Marcel, S., Altmann, F., Kolarich, D., Drakakaki, G., Fischer, R., Christou, P., \& Stoger, E. (2004). Unexpected deposition patterns of recombinant proteins in postendoplasmic reticulum compartments of wheat endosperm. Plant Physiology, 136, 34573466.

Arcalis, E., Stadlmann, J., Marcel, S., Drakakaki, G., Winter, V., Rodriguez, J., Fischer, R., Altmann, F., \& Stoger, E. (2010). The changing fate of a secretory glycoprotein in developing maize endosperm. Plant Physiology, 153, 693-702.

Beaugrand, J., Cronier, D., Thiebeau, P., Schreiber, L., Debeire, P., \& Chabbert, B. (2004). Structure, chemical composition, and xylanase degradation of external layers isolated from developing wheat grain. Journal of Agricultural and Food Chemistry, 52, 71087117.

Beaugrand, J., Paes, G., Reis, D., Takahashi, M., Debeire, P., O'Donohue, M., \& Chabbert, B. (2005). Probing the cell wall heterogeneity of micro-dissected wheat caryopsis using both active and inactive forms of a GH11 xylanase. Planta, 222, 246-257.

Beaugrand, J., Reis, D., Guillon, F., Debeire, P., \& Chabbert, B. (2004). Xylanase-mediated hydrolysis of wheat bran: evidence for subcellular heterogeneity of cell walls. International Journal of Plant Sciences, 165, 553-563.

Capparelli, R., Amoroso, M. G., Palumbo, D., Iannaccone, M., Faleri, C., \& Cresti, M. (2005). Two plant puroindolines colocalize in wheat seed and in vitro synergistically fight against pathogens. Plant Molecular Biology, 58, 857-867.

Carjuzaa, P., Castellión, M., Distéfano, A. J., del Vas, M., \& Maldonado, S. (2008). Detection and subcellular localization of dehydrin-like proteins in quinoa (Chenopodium quinoa Willd.) embryos. Protoplasma, 233, 149-156.

Carpita, N. C., \& McCann, M. C. (2010). The maize mixed-linkage (1 $\rightarrow 3),(1 \rightarrow 4)-\beta$-d-glucan polysaccharide is synthesized at the Golgi membrane. Plant Physiology, 153, 1362-1371.

Chen, D. H., Chyan, C. L., Jiang, P. L., Chen, C. S., \& Tzen, J. T. (2012). The same oleosin isoforms are present in oil bodies of rice embryo and aleurone layer while caleosin exists only in those of the embryo. Plant Physiology and Biochemistry, 60, 18-24.

Chikwamba, R. K., Scott, M. P., Mejía, L. B., Mason, H. S., \& Wang, K. (2003). Localization of a bacterial protein in starch granules of transgenic maize kernels. Proceedings of the National Academy of Sciences, 100, 11127-11132.

Clausen, M. H., Ralet, M.-C., Willats, W. G. T., McCartney, L., Marcus, S. E., Thibault, J.-F., \& Knox, J. P. (2004). A monoclonal antibody to feruloylated-(1 $\rightarrow 4)-\beta$-d-galactan. Planta, 219, 1036-1041.

Clausen, M. H., Willats, W. G. T., \& Knox, J. P. (2003). Synthetic methyl hexagalacturonate hapten inhibitors of anti-homogalacturonan monoclonal antibodies LM7, JIM5 and JIM7. Carbohydrate Research, 338, 1797-1800. 
Constantin, C., Quirce, S., Grote, M., Touraev, A., Swoboda, I., Stoecklinger, A., Mari, A., Thalhamer, J., Heberle-Bors, E., \& Valenta, R. (2008). Molecular and immunological characterization of a wheat serine proteinase inhibitor as a novel allergen in baker's asthma. The Journal of Immunology, 180, 7451-7460.

Dornez, E., Cuyvers, S., Holopainen, U., Nordlund, E., Poutanen, K., Delcour, J. A., \& Courtin, C. M. (2011). Inactive fluorescently labeled xylanase as a novel probe for microscopic analysis of arabinoxylan containing cereal cell walls. Journal of Agricultural and Food Chemistry, 59, 6369-6375.

Dornez, E., Holopainen, U., Cuyvers, S., Poutanen, K., Delcour, J. A., Courtin, C. M., \& Nordlund, E. (2011). Study of grain cell wall structures by microscopic analysis with four different staining techniques. Journal of Cereal Science, 54, 363-373.

Dwivany, F. M., Yulia, D., Burton, R. A., Shirley, N. J., Wilson, S. M., Fincher, G. B., Bacic, A., Newbigin, E. J., \& Doblin, M. S. (2009). The cellulose-synthase like C (CSLC) family of barley includes members that are integral membrane proteins targeted to the plasma membrane. Molecular Plant, 2, 1025-1039.

Finnie, C., Sultan, A., \& Grasser, K. D. (2011). From protein catalogues towards targeted proteomics approaches in cereal grains. Phytochemistry, 72, 1145-1153.

Furukawa, S., Mizuma, T., Kiyokawa, Y., Masumura, T., Tanaka, K., \& Wakai, Y. (2003). Distribution of storage proteins in low-glutelin rice seed determined using a fluorescent antibody. Journal of Bioscience and Bioengineering, 96, 467-473.

Galuszka, P., Frebortova, J., Luhova, L., Bilyeu, K. D., English, J. T., \& Frebort, I. (2005). Tissue localization of cytokinin dehydrogenase in maize: possible involvement of quinone species generated from plant phenolics by other enzymatic systems in the catalytic reaction. Plant \& Cell Physiology, 46, 716-728.

Gil-Humanes, J., Pistón, F., Shewry, P. R., Tosi, P., \& Barro, F. (2011). Suppression of gliadins results in altered protein body morphology in wheat. Journal of Experimental Botany.

Guillon, F., Bouchet, B., Jamme, F., Robert, P., Quemener, B., Barron, C., Larre, C., Dumas, P., \& Saulnier, L. (2011). Brachypodium distachyon grain: characterization of endosperm cell walls. Journal of Experimental Botany, 62, 1001-1015.

Guillon, F., Tranquet, O., Quillien, L., Utille, J.-P., Ordaz Ortiz, J. J., \& Saulnier, L. (2004). Generation of polyclonal and monoclonal antibodies against arabinoxylans and their use for immunocytochemical location of arabinoxylans in cell walls of endosperm of wheat. Journal of Cereal Science, 40, 167-182.

Heneen, W. K., Karlsson, G., Brismar, K., Gummeson, P. O., Marttila, S., Leonova, S., Carlsson, A. S., Bafor, M., Banas, A., Mattsson, B., Debski, H., \& Stymne, S. (2008). Fusion of oil bodies in endosperm of oat grains. Planta, 228, 589-599.

Hennegan, K., Yang, D., Nguyen, D., Wu, L., Goding, J., Huang, J., Guo, F., Huang, N., \& Watkins, S. C. (2005). Improvement of human lysozyme expression in transgenic rice 
grain by combining wheat (Triticum aestivum) puroindoline b and rice (Oryza sativa) Gt1 promoters and signal peptides. Transgenic Research, 14, 583-592.

Hensel, G. (2011). Genetic transformation of Triticeae cereals for molecular farming. In M. Alvarez (Ed.), Genetic Transformation (pp. 171-190): InTech.

Holding, D. R., Otegui, M. S., Li, B., Meeley, R. B., Dam, T., Hunter, B. G., Jung, R., \& Larkins, B. A. (2007). The maize floury1 gene encodes a novel endoplasmic reticulum protein involved in zein protein body formation. Plant Cell, 19, 2569-2582.

Jerkovic, A., Kriegel, A. M., Bradner, J. R., Atwell, B. J., Roberts, T. H., \& Willows, R. D. (2010). Strategic distribution of protective proteins within bran layers of wheat protects the nutrient-rich endosperm. Plant Physiology, 152, 1459-1470.

Kang, B.-H., Xiong, Y., Williams, D. S., Pozueta-Romero, D., \& Chourey, P. S. (2009). Miniature1-encoded cell wall invertase is essential for assembly and function of wall-ingrowth in the maize endosperm transfer cell. Plant Physiology, 151, 1366-1376.

Kawagoe, Y., Suzuki, K., Tasaki, M., Yasuda, H., Akagi, K., Katoh, E., Nishizawa, N. K., Ogawa, M., \& Takaiwa, F. (2005). The critical role of disulfide bond formation in protein sorting in the endosperm of rice. Plant Cell, 17, 1141-1153.

Kawakatsu, T., Hirose, S., Yasuda, H., \& Takaiwa, F. (2010). Reducing rice seed storage protein accumulation leads to changes in nutrient quality and storage organelle formation. Plant Physiology, 154, 1842-1854.

Kumagai, T., Kawamura, H., Fuse, T., Watanabe, T., Saito, Y., Masumura, T., Watanabe, R., \& Kadowaki, M. (2006). Production of rice protein by alkaline extraction improves its digestibility. Journal of Nutritional Science and Vitaminology, 52, 467-472.

Larré, C., Penninck, S., Bouchet, B., Lollier, V., Tranquet, O., Denery-Papini, S., Guillon, F., \& Rogniaux, H. (2010). Brachypodium distachyon grain: identification and subcellular localization of storage proteins. Journal of Experimental Botany, 61, 1771-1783.

Lesage, V. S., Bouchet, B., Rhazi, L., Elmorjani, K., Branlard, G., \& Marion, D. (2011). New insight into puroindoline function inferred from their subcellular localization in developing hard and soft near-isogenic endosperm and their relationship with polymer size of storage proteins. Journal of Cereal Science, 53, 231-238.

Liu, H., Hedley, P., Cardle, L., Wright, K. M., Hein, I., Marshall, D., \& Waugh, R. (2005). Characterisation and functional analysis of two barley caleosins expressed during barley caryopsis development. Planta, 221, 513-522.

Loussert, C., Popineau, Y., \& Mangavel, C. (2008). Protein bodies ontogeny and localization of prolamin components in the developing endosperm of wheat caryopses. Journal of Cereal Science, 47, 445-456.

Lovegrove, A., Wilkinson, M. D., Freeman, J., Pellny, T. K., Tosi, P., Saulnier, L., Shewry, P. R., \& Mitchell, R. A. (2013). RNA interference suppression of genes in glycosyl transferase families 43 and 47 in wheat starchy endosperm causes large decreases in arabinoxylan content. Plant Physiology, 163, 95-107. 
Marcus, S. E., Blake, A. W., Benians, T. A. S., Lee, K. J. D., Poyser, C., Donaldson, L., Leroux, O., Rogowski, A., Petersen, H. L., Boraston, A. B., Gilbert, H. J., Willats, W. G. T., \& Knox, J. P. (2010). Restricted access of proteins to mannan polysaccharides in intact plant cell walls. The Plant Journal, 64, 191-203.

Marcus, S. E., Verhertbruggen, Y., Herve, C., Ordaz-Ortiz, J. J., Farkas, V., Pedersen, H. L., Willats, W. G., \& Knox, J. P. (2008). Pectic homogalacturonan masks abundant sets of xyloglucan epitopes in plant cell walls. BMC Plant Biology, 8, 60.

McCartney, L., Marcus, S. E., \& Knox, J. P. (2005). Monoclonal antibodies to plant cell wall xylans and arabinoxylans. Journal of Histochemistry and Cytochemistry :, 53, 543-546.

Mills, E. N. C., Parker, M. L., Wellner, N., Toole, G., Feeney, K., \& Shewry, P. R. (2005). Chemical imaging: the distribution of ions and molecules in developing and mature wheat grain. Journal of Cereal Science, 41, 193-201.

Mitea, C., Kooy-Winkelaar, Y., van Veelen, P., de Ru, A., Drijfhout, J. W., Koning, F., \& Dekking, L. (2008). Fine specificity of monoclonal antibodies against celiac diseaseinducing peptides in the gluteome. The American Journal of Clinical Nutrition, 88, 10571066.

Mohammadi, M., Zaidi, M. A., Ochalski, A., Tanchak, M., \& Altosaar, I. (2007). Immunodetection and immunolocalization of tryptophanins in oat (Avena sativa $\mathrm{L}$.) seeds. Plant Science, 172, 579-587.

Nagamine, A., Matsusaka, H., Ushijima, T., Kawagoe, Y., Ogawa, M., Okita, T. W., \& Kumamaru, T. (2011). A role for the cysteine-rich $10 \mathrm{kDa}$ prolamin in protein body I formation in rice. Plant and Cell Physiology, 52, 1003-1016.

Ohdaira, Y., Masumura, T., Nakatsuka, N., Shigemitsu, T., Saito, Y., \& Sasaki, R. (2011). Analysis of storage protein distribution in rice grain of seed-protein mutant cultivars by immunofluorescence microscopy. Plant Production Science, 14, 219-228.

Ordaz-Ortiz, J. J., Guillon, F., Tranquet, O., Dervilly-Pinel, G., Tran, V., \& Saulnier, L. (2004). Specificity of monoclonal antibodies generated against arabinoxylans of cereal grains. Carbohydrate Polymers, 57, 425-433.

Pattathil, S., Avci, U., Baldwin, D., Swennes, A. G., McGill, J. A., Popper, Z., Bootten, T., Albert, A., Davis, R. H., Chennareddy, C., Dong, R., O'Shea, B., Rossi, R., Leoff, C., Freshour, G., Narra, R., O'Neil, M., York, W. S., \& Hahn, M. G. (2010). A comprehensive toolkit of plant cell wall glycan-directed monoclonal antibodies. Plant Physiology, 153, 514-525.

Pellny, T. K., Lovegrove, A., Freeman, J., Tosi, P., Love, C. G., Knox, J. P., Shewry, P. R., \& Mitchell, R. A. (2012). Cell walls of developing wheat starchy endosperm: comparison of composition and RNA-Seq transcriptome. Plant Physiology, 158, 612-627.

Philippe, S., Saulnier, L., \& Guillon, F. (2006). Arabinoxylan and (1-->3),(1-->4)-beta-glucan deposition in cell walls during wheat endosperm development. Planta, 224, 449-461. 
Philippe, S., Tranquet, O., Utille, J. P., Saulnier, L., \& Guillon, F. (2007). Investigation of ferulate deposition in endosperm cell walls of mature and developing wheat grains by using a polyclonal antibody. Planta, 225, 1287-1299.

Rampitsch, C., Ames, N., Storsley, J., \& Marien, L. (2003). Development of a monoclonal antibody-based enzyme-linked immunosorbent assay to quantify soluble beta-glucans in oats and barley. Journal of Agricultural and Food Chemistry, 51, 5882-5887.

Reyes, F. C., Chung, T., Holding, D., Jung, R., Vierstra, R., \& Otegui, M. S. (2011). Delivery of prolamins to the protein storage vacuole in maize aleurone cells. Plant Cell, 23, 769-784.

Robert, P., Jamme, F., Barron, C., Bouchet, B., Saulnier, L., Dumas, P., \& Guillon, F. (2011). Change in wall composition of transfer and aleurone cells during wheat grain development. Planta, 233, 393-406.

Saito, Y., Kishida, K., Takata, K., Takahashi, H., Shimada, T., Tanaka, K., Morita, S., Satoh, S., \& Masumura, T. (2009). A green fluorescent protein fused to rice prolamin forms protein body-like structures in transgenic rice. Journal of Experimental Botany, 60, 615-627.

Saito, Y., Nakatsuka, N., Shigemitsu, T., Tanaka, K., Morita, S., Satoh, S., \& Masumura, T. (2008). Thin frozen film method for visualization of storage proteins in mature rice grains. Bioscience, Biotechnology, and Biochemistry, 72, 2779-2781.

Saulnier, L., Guillon, F., Sado, P. E., \& Rouau, X. (2007). Plant cell wall polysaccharides in storage organs: xylans (food applications). In J. P. Kamerling (Ed.), Comprehensive Glycoscience (pp. 653-689). Oxford: Elsevier.

Saulnier, L., Sado, P.-E., Branlard, G., Charmet, G., \& Guillon, F. (2007). Wheat arabinoxylans: Exploiting variation in amount and composition to develop enhanced varieties. Journal of Cereal Science, 46, 261-281.

Shigemitsu, T., Masumura, T., Morita, S., \& Satoh, S. (2013). Accumulation of rice prolaminGFP fusion proteins induces ER-derived protein bodies in transgenic rice calli. Plant Cell Reports, 32, 389-399.

Suliman, M., Chateigner-Boutin, A. L., Francin-Allami, M., Partier, A., Bouchet, B., Salse, J., Pont, C., Marion, J., Rogniaux, H., Tessier, D., Guillon, F., \& Larre, C. (2013). Identification of glycosyltransferases involved in cell wall synthesis of wheat endosperm. Journal of Proteomics, 78, 508-521.

Takahashi, H., Saito, Y., Kitagawa, T., Morita, S., Masumura, T., \& Tanaka, K. (2005). A novel vesicle derived directly from endoplasmic reticulum is involved in the transport of vacuolar storage proteins in rice endosperm. Plant \& Cell Physiology, 46, 245-249.

Takeuchi, M., Takabe, K., \& Mineyuki, Y. (2010). Immunoelectron microscopy of cryofixed and freeze-substituted plant tissues. In S. D. Schwartzbach \& T. Osafune (Eds.), Immunoelectron Microscopy (Vol. 657, pp. 155-165): Humana Press.

Tian, L., Dai, L. L., Yin, Z. J., Fukuda, M., Kumamaru, T., Dong, X. B., Xu, X. P., \& Qu, L. Q. (2013). Small GTPase Sar1 is crucial for proglutelin and $\alpha$-globulin export from the 
endoplasmic reticulum in rice endosperm. Journal of Experimental Botany, 64, 28312845 .

Toole, G. A., Le Gall, G., Colquhoun, I. J., Drea, S., Opanowicz, M., Bedő, Z., Shewry, P. R., \& Mills, E. N. C. (2012). Spectroscopic analysis of diversity in the spatial distribution of arabinoxylan structures in endosperm cell walls of cereal species in the HEALTHGRAIN diversity collection. Journal of Cereal Science, 56, 134-141.

Tosi, P., Gritsch, C. S., He, J., \& Shewry, P. R. (2011). Distribution of gluten proteins in bread wheat (Triticum aestivum) grain. Annals of Botany, 108, 23-35.

Tosi, P., Parker, M., Gritsch, C. S., Carzaniga, R., Martin, B., \& Shewry, P. R. (2009). Trafficking of storage proteins in developing grain of wheat. Journal of Experimental Botany, 60, 979-991.

Tranquet, O., Larré, C., \& Denery-Papini, S. (2012). Selection of a monoclonal antibody for detection of gliadins and glutenins: A step towards reliable gluten quantification. Journal of Cereal Science, 56, 760-763.

Tranquet, O., Saulnier, L., Utille, J.-P., Ralph, J., \& Guillon, F. (2009). Monoclonal antibodies to p-coumarate. Phytochemistry, 70, 1366-1373.

Van Herpen, T. W., Riley, M., Sparks, C., Jones, H. D., Gritsch, C., Dekking, E. H., Hamer, R. J., Bosch, D., Salentijn, E. M., Smulders, M. J., Shewry, P. R., \& Gilissen, L. J. (2008). Detailed analysis of the expression of an alpha-gliadin promoter and the deposition of alpha-gliadin protein during wheat grain development. Annals of Botany, 102, 331-342.

Verhertbruggen, Y., Marcus, S. E., Haeger, A., Ordaz-Ortiz, J. J., \& Knox, J. P. (2009). An extended set of monoclonal antibodies to pectic homogalacturonan. Carbohydrate Research, 344, 1858-1862.

Wakasa, Y., Yang, L., Hirose, S., \& Takaiwa, F. (2009). Expression of unprocessed glutelin precursor alters polymerization without affecting trafficking and accumulation. Journal of Experimental Botany, 60, 3503-3511.

Wakasa, Y., Yasuda, H., Oono, Y., Kawakatsu, T., Hirose, S., Takahashi, H., Hayashi, S., Yang, L., \& Takaiwa, F. (2011). Expression of ER quality control-related genes in response to changes in BiP1 levels in developing rice endosperm. The Plant Journal, 65, 675-689.

Wang, S., Yu, Z., Cao, M., Shen, X., Li, N., Li, X., Ma, W., Weissgerber, H., Zeller, F., Hsam, S., \& Yan, Y. (2013). Molecular mechanisms of HMW glutenin subunits from 1S(1) genome of Aegilops longissima positively affecting wheat breadmaking quality. PLoS One, 8, e58947.

Washida, H., Sugino, A., Kaneko, S., Crofts, N., Sakulsingharoj, C., Kim, D., Choi, S. B., Hamada, S., Ogawa, M., Wang, C., Esen, A., Higgins, T. J., \& Okita, T. W. (2009). Identification of cis-localization elements of the maize 10-kDa delta-zein and their use in targeting RNAs to specific cortical endoplasmic reticulum subdomains. Plant Journal, 60, 146-155. 
Wiley, P. R., Tosi, P., Evrard, A., Lovegrove, A., Jones, H. D., \& Shewry, P. R. (2007). Promoter analysis and immunolocalisation show that puroindoline genes are exclusively expressed in starchy endosperm cells of wheat grain. Plant Molecular Biology, 64, 125-136.

Willats, W. G. T., \& Knox, J. P. (2003). Molecules in context: probes for cell wall analysis. In J. K. C. Rose (Ed.), The Plant Cell Wall (pp. 92-110). Oxford: Blackwell.

Willats, W. G. T., McCartney, L., Steele-King, C. G., Marcus, S. E., Mort, A., Huisman, M., Alebeek, G.-J., Schols, H. A., Voragen, A. G. J., Goff, A., Bonnin, E., Thibault, J.-F., \& Knox, J. P. (2004). A xylogalacturonan epitope is specifically associated with plant cell detachment. Planta, 218, 673-681.

Wilson, S. M., \& Bacic, A. (2012). Preparation of plant cells for transmission electron microscopy to optimize immunogold labeling of carbohydrate and protein epitopes. Nature Protocols, 7, 1716-1727.

Wilson, S. M., Burton, R. A., Collins, H. M., Doblin, M. S., Pettolino, F. A., Shirley, N., Fincher, G. B., \& Bacic, A. (2012). Pattern of deposition of cell wall polysaccharides and transcript abundance of related cell wall synthesis genes during differentiation in barley endosperm. Plant Physiology, 159, 655-670.

Wilson, S. M., Burton, R. A., Doblin, M. S., Stone, B. A., Newbigin, E. J., Fincher, G. B., \& Bacic, A. (2006). Temporal and spatial appearance of wall polysaccharides during cellularization of barley (Hordeum vulgare) endosperm. Planta, 224, 655-667.

Yasuda, H., Hirose, S., Kawakatsu, T., Wakasa, Y., \& Takaiwa, F. (2009). Overexpression of BiP has inhibitory effects on the accumulation of seed storage proteins in endosperm cells of rice. Plant \& Cell Physiology, 50, 1532-1543.

Zhang, S.-J., Song, X.-Q., Yu, B.-S., Zhang, B.-C., Sun, C.-Q., Knox, J. P., \& Zhou, Y.-H. (2011). Identification of quantitative trait loci affecting hemicellulose characteristics based on cell wall composition in a wild and cultivated rice species. Molecular Plant. 